\title{
Evaluation of the Proliferation Markers in Interstitial Cystitis/Bladder Pain Syndrome: An Experimental Model
}

\author{
Interstisyel Sistit/Mesane Ağrısı Sendromu Deneysel Modellerinde Proliferasyon \\ Belirteçlerinin Değerlendirilmesi
}

ه Rashad Sholan

Republican Centre of Diagnosis and Treatment, Department of Kidney Diseases and Transplantology, Baku, Azerbaijan

\section{Abstract}

Aim: The aim of this study was to determine the level of nerve growth factor (NGF) and epidermal growth factor (EGF) in an animal model of interstitial cystitis/bladder pain syndrome (IC) BPS) and identify correlations between them.

Methods: IC/BPS modeling was performed on white New Zealand female rabbits divided into six groups depending on the methods of modeling. Urine and blood levels of NGF and EGF were determined by the ELISA method. The correlation between the indicators was calculated by the Pearson correlation coefficient.

Results: An increase in the concentration of NGF and EGF was detected in animals of all experimental groups; a significantly high level of these factors in blood and urine was determined in a toxic model created with the introduction of urine into the submucosal layer of the bladder wall. The correlation between NGF and EGF tended to increase by 14 days. There was a strong correlation between these indicators in the urine of animals with IC/BPS created by a $70 \%$ alcohol solution $(p<0.01)$. A strong correlation between these indicators was observed in blood of animals with IC/BPS created by the administration of protamine sulfate and in animals of toxic model $(p<0.01)$.

Conclusion: An increase in the levels of proliferation markers is likely due to chronic inflammation process and urine toxicity. The presence of a correlation between NGF and EGF and their strengthening as the disease progresses indicates an increase in the proliferation processes. Proliferation markers can be used in the diagnosis and monitoring of IC/BPS.

Keywords: Interstitial cystitis/bladder pain syndrome, proliferation, nerve growth factor, correlation, epidermal growth factor, animal models, experimental model

\section{Öz}

Amaç: Bu çalışmanın amacı, interstisyel sistit/mesane ağrısı (IC) BPS) sendromu deneysel modellerine sahip hayvanlarda sinir büyüme faktörü (NGF) ve epidermal büyüme faktörü (EGF) düzeylerini belirlemek ve aralarındaki ilişkileri tespit etmektir.

Yöntemler: Modelleme yöntemlerine bağlı olarak altı gruba ayrılan beyaz Yeni Zelanda dişi tavşanlarında IC/BPS modellemesi yapıldı. Sinir büyüme faktörü ve epidermal büyüme faktörü ELISA yöntemi ile kanda ve idrarda belirlendi. Göstergeler arasındaki korelasyon Pearson katsayısı ile hesaplandı.

Bulgular: Tüm deney gruplarındaki hayvanlarda sinir büyüme faktörü ve epidermal büyüme faktörü konsantrasyonunda bir artış tespit edildi; Kan ve idrarda bu faktörlerin anlamlı derecede yüksek olduğu, idrarın mesanenin submukoz tabakasına katılmasıyla toksik bir modelde tespit edildi. Sinir büyüme faktörü ve epidermal büyüme faktörü arasındaki korelasyon 14 gün artma eğilimindeydi. Bu göstergeler arasında hayvanların idrarında \%70 alkol solüsyonunun oluşturduğu IC/BPS ile güçlü bir korelasyon vardı $(p<0,01)$. Bu göstergeler arasında kuvvetli bir korelasyon, protamin sülfat uygulaması ile yaratılan IC/BPS'li hayvanların kanında ve toksik modeli olan hayvanlarda gözlendi $(p<0,01)$.

Sonuç: Proliferasyon belirteçlerinde artış, kronik enflamasyon süreci ve idrar toksisitesinden kaynaklanıyor olabilir. Sinir büyüme faktörü ile epidermal büyüme faktörü arasında bir korelasyonun varlığı ve hastalık ilerledikçe güçlenmesi proliferasyon süreçlerinde bir artışa işaret eder. Proliferasyon belirteçlerinin belirlenmesi, tanı kriterleri ve IC/BPS'nin izlenmesi olarak kullanılabilir.

Anahtar Sözcükler: Interstisyel sistit/mesane ağrısı sendromu, proliferasyon, sinir büyüme faktörü, korelasyon, epidermal büyüme faktörü, hayvan modelleri, deneysel model
Address for Correspondence/Yazışma Adresi: Rashad Sholan, Republican Centre of Diagnosis and Treatment, Department of Kidney Diseases and Transplantology, Baku, Azerbaijan Phone: +994 502125357 E-mail: drrashad@hotmail.com ORCID: orcid.org/0000-0002-1047-167X Received/Geliş Tarihi: 19 October 2019 Accepted/Kabul Tarihi: 29 January 2020

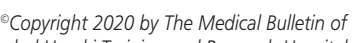
istanbul Haseki Training and Research Hospital The Medical Bulletin of Haseki published by Galenos Yayınevi. Telif Hakkı 2020 istanbul Haseki Eğitim ve Araştırma Hastanesi Haseki Tıp Bülteni, Galenos Yayınevi tarafından yayınlanmıştır. 


\section{Introduction}

Interstitial cystitis/bladder pain syndrome (IC/BPS), being a chronic pathology, is accompanied by debilitating pain and discomfort in the bladder. The nature of IC/ BPS is not fully understood. However, it was established that this disease has a polyetiological origin as evidenced by its characteristic variety of symptoms (1-3). There are several proposed theories for the etiology of IC/BPS and each of them has its pros and cons: neuropathy, immunological theory, stagnation in the lymphatic system, influence of the infectious factors, corrosion of the mucous layer of the bladder, psychosomatic theory (formation of the disease against the background of psychological conditions), failures in the exchange of nitric oxide, influence of toxins, etc. None of these theories have been proven or completely refuted, but researchers considered the most possible last of these: toxic substances from urine seep through the mucous membrane to the bladder wall and cause inflammation (4-7).

Due to the insufficient number of studies on this pathology, the exact causes of its development are still problematic. However, researchers have number of reasons to distinguish some key triggering factors including chronic infectious and inflammatory processes of the genitourinary system (the local immune response is able to produce certain chemicals for a long time which ultimately provoke the development of the IC/BPS), certain elements released during urination irritate the mucous layer, manifestation of autoimmune reactions, concomitant pathology of other organs and systems affecting the urogenital system, and morbid diseases of the central nervous system $(5,8,9)$.

Researchers are currently focusing on the role of urinary factors including urinary nerve growth factor (NGF) and epidermal growth factor (EGF). The role of these factors as diagnostic biomarkers has not been sufficiently studied. In this regard, it is important to study the level of these markers in the blood and urine in IC/BPS. Hence, the purpose of this study was to determine the level of NGF and EGF in animal models of IC/BPS and to determine the correlation between them.

\section{Methods}

This research has been approved by the Ethics Committee of the Republican Medical Diagnostic Center (protocol no: 136, date: 02.09.2018). The study was performed in accordance with the Guide for the Care and Use of Laboratory Animals (NRC - The National Research Council) (10). Experimental models of IC/BPS were created in white New Zealand female rabbits weighing $1500-2000 \mathrm{~g}$.
Pathophysiology of IC/BPS is complex and animal models are used to understand the underlying mechanisms (11-13). The animals were exposed to chemical and toxic substances in order to induce bladder inflammation and were divided into six groups: IC/BPS was provoked by instillation of a $70 \%$ alcohol solution, protamine sulfate (10 $\mathrm{mg})$ and $\mathrm{HCl}(0.2 \mathrm{~mL} 0.5 \%)$ into the bladder of the $1^{\text {st }}(n=8), 2^{\text {nd }}(n=7)$ and the $3^{\text {rd }}$ group $(n=8)$ of animals, respectively. In animals of the $4^{\text {th }}$ group, IC/BPS model was created on the basis of one of the etiological theories of the IC, according to which uric toxicity leads to damage of the glycosaminoglycan layer $(14,15)$. A suprapubic section was done and after which a urine sample taken from the bladder using a $0.5 \mathrm{~cm}^{3}$ syringe with 30 -gauge needle inserted through the mucous layer of the bladder. $10 \mathrm{~mL}$ of $\mathrm{NaCl}$ were injected into the bladder wall of the animals of the $5^{\text {th }}$ group $(n=7)$; animals from $6^{\text {th }}$ group $(n=8)$ formed a control group-they were not given anything.

NGF was determined by enzyme-linked immunosorbent assay (ELISA) using a set of NGF Emax ${ }^{\circledR}$ apparatus Medispec 6000M (Israel). Urine and blood levels of EGF were determined by ELISA using an EGF kit (Cusabio Biotech Co., Ltd., China). Marker concentrations were determined in blood and urine. The measurements were carried out $1^{\text {st }}$ and $14^{\text {th }}$ days after the creation of the experimental model.

\section{Statistical Analysis}

Statistical processing of the obtained data was carried out using the programs "Statistical for Windows 8.0" and "Microsoft Excel". Average value and standard deviation of the mean were calculated. A p value of less than 0.05 was considered statistically significant. The correlation between blood and urine biomarkers was calculated by the Pearson's correlation coefficient.

\section{Results}

The levels of the NGF in experimental groups are presented in Table 1. Analysis of NGF concentration on the first day of the study revealed a statistically significant increase in the biomarker level in the blood of all groups compared to the control group; in the $1^{\text {st }}$ group, the NGF level exceeded that in the control group by $46.0 \%$ $(p<0.05)$, in the $2^{\text {nd }}$ group-by $41.0 \%(p<0.05)$, in the $3^{\text {rd }}$ group-by $60.4 \%(p<0.01)$, in the $4^{\text {th }}$ and $5^{\text {th }}$ groups-by $71.3(p<0.01)$ and $44.0 \%(p<0.05)$, respectively. The level of NGF in the blood was statistically significantly higher in the $4^{\text {th }}$ group than in other groups $(p<0.05)$. In the same period, the urine level of NGF was significantly higher in the $4^{\text {th }}$ group than in the control group (by $68.2 \%, p<0.01$ ); in other groups, the difference in the level of NGF in the urine compared with the control group was insignificant. After 14 days increased blood biomarker level remained 
in all groups relative to the control group $(p<0.05)$, but the difference was most evident in the $4^{\text {th }}$ group- $90.1 \%$ $(p<0.001)$. The urine concentration of NGF in all groups was higher than in the control group, but a statistically significant difference an increase in the level of NGF in the urine compared with the control group was observed in group 4; $85.0 \%(p<0.001)$.

There was a wide variation of NGF values in the blood for the first day among the $3^{\text {rd }}, 4^{\text {th }}$ and the $5^{\text {th }}$ animal groups and, in urine-in the $4^{\text {th }}$ group. After 14 days, a significant variability in values was observed in the blood of the animals of the $1^{\text {st }}$ and $4^{\text {th }}$ groups, in urine-only in the $4^{\text {th }}$ group.

An intragroup analysis of NGF levels in each of the experimental groups revealed a dissimilar tendency. In the $1^{\text {st }}$ group, when comparing NGF levels at different periods of observation, there was a tendency to increase both in blood and urine. In this group, compared with the initial value, there was an increase in the blood NGF level by $35.1 \%(p<0.05)$, in the urine-by $8.7 \% 14$ days after creation of the model, On the $14^{\text {th }}$ day of the study, there was a slight decrease in the level of NGF in the $2^{\text {nd }}$ group. The blood concentration of NGF in the $3^{\text {rd }}$ group decreased by $29.3 \%$, while urine concentration of NGF increased by $14.3 \%$. In the $4^{\text {th }}$ group after 14 days of urine injection, compared with the first day, a significant increase in the NGF level in blood and urine was determined, by $65.5 \%(p<0.01)$ and $52.7 \%$ $(p<0.05)$, respectively. In the $5^{\text {th }}$ group, a decrease in NGF concentration in the blood and urine was noted: the difference with the initial period of observation in the blood was $30.8 \%$, in the urine-30.5\%.

Fourteen days later, compared with the first day after urine injection, a significant increase in the level of NGF blood and urine was determined in group 4, by $65.5 \%$ $(p<0.01)$ and $52.7 \%(p<0.05)$ respectively.

The level of EGF in the experimental groups is presented in Table 2.

One day after modeling, there was no significant difference in blood level of EGF between the experimental groups and the control group. A relatively high level of EGF in the blood was detected among animals of the $3^{\text {rd }}$ group, which exceeded that in the intact group by $15.6 \%$; and the blood concentration of EGF in the $1^{\text {st }}$ and the $5^{\text {th }}$ groups was $20.4 \%$ and 3.5\% lower than in control group, respectively.

One day after modeling, there was no significant difference in the blood level of EGF between the experimental groups and the control group. A relatively high level of EGF in the blood was detected in animals of $3^{\text {rd }}$ group, which exceeded that in the control group by $15.6 \%$, and, the blood concentration of EGF in the $1^{\text {st }}$ and $5^{\text {th }}$ groups was $20.4 \%$ and $3.5 \%$ lower than in the control group, respectively. Significant differences in EGF in the blood were also noted between the IC/BPS models. At the same time, statistically significant higher level of EGF in urine was revealed in the $3^{\text {rd }}$ and $4^{\text {th }}$ groups compared with the control group-by $48.2 \%(p<0.05)$ and $34.6 \%$ $(p<0.05)$.

After 14 days, the highest level of EGF in the blood and urine was determined in animals of the $4^{\text {th }}$ group; the level of EGF in the blood and urine were $63.1 \%$ and $49.2 \%$ higher than in the control group, respectively $(p<0.01$ and $p<0.05$, respectively). The EGF level in urine was 2.6 times lower in the $5^{\text {th }}$ group than in the control group $(p<0.01)$.

A comparative analysis of the EGF level among groups after $1^{\text {st }}$ and $14^{\text {th }}$ days showed a decrease in the EGF concentration in the blood and urine in the $2^{\text {nd }}$ group after

\begin{tabular}{|c|c|c|c|c|}
\hline \multirow{2}{*}{ Groups } & \multicolumn{2}{|l|}{1 day } & \multicolumn{2}{|l|}{14 days } \\
\hline & Blood, ng/mL & Urine, ng/mL & Blood, ng/mL & Urine, $\mathrm{ng} / \mathrm{mL}$ \\
\hline $1(n=8)$ & $\begin{array}{l}12.95 \pm 2.34 \\
(8.5,15.4)\end{array}$ & $\begin{array}{l}9.71 \pm 0.51 \\
(8.5,10.5)\end{array}$ & $\begin{array}{l}19.95 \pm 7.47^{*} \\
(14.1,47)\end{array}$ & $\begin{array}{l}10.64 \pm 0.37 \\
(10.1,11.4)\end{array}$ \\
\hline $2(n=7)$ & $\begin{array}{l}11.84 \pm 1.33 \\
(9.4,15.3)\end{array}$ & $\begin{array}{l}11.36 \pm 2.78 \\
(8.1,21.1)\end{array}$ & $\begin{array}{l}11.34 \pm 0.49 \\
(10.3,12.2)\end{array}$ & $\begin{array}{l}9.34 \pm 0.55 \\
(8.1,10.5)\end{array}$ \\
\hline $3(n=8)$ & $\begin{array}{l}17.64 \pm 8.43 \\
(10.2,48.3)\end{array}$ & $\begin{array}{l}10.51 \pm 1.06 \\
(8.5,13.2)\end{array}$ & $\begin{array}{l}13.64 \pm 0.86 \\
(12.1,15.3)\end{array}$ & $\begin{array}{l}12.26 \pm 1.83 \\
(9.8,17.4)\end{array}$ \\
\hline $4(n=15)$ & $\begin{array}{l}24.33 \pm 16.30^{*} \\
(6.9,68)\end{array}$ & \begin{tabular}{|l}
$30.39 \pm 27.46^{*}$ \\
$(9.6,155.1)$
\end{tabular} & $\begin{array}{l}70.62 \pm 21.63^{*}, \text { ** } \\
(42.5,125.8)\end{array}$ & $\begin{array}{l}64.26 \pm 22.84^{*}, \text {,* } \\
(26.4,155.1)\end{array}$ \\
\hline $5(n=7)$ & $\begin{array}{l}12.47 \pm 5.02 \\
(4.7,21.8)\end{array}$ & $\begin{array}{l}13.3 \pm 1.91 \\
(9.6,16.6)\end{array}$ & $\begin{array}{l}9.53 \pm 0.95 \\
(7.8,10.9)\end{array}$ & $\begin{array}{l}10.19 \pm 1.01 \\
(8.5,12.0)\end{array}$ \\
\hline $6(n=8)$ & $\begin{array}{l}6.99 \pm 1.84 \\
(4.3,9.4)\end{array}$ & $\begin{array}{l}9.65 \pm 0.6 \\
(8.5,10.7)\end{array}$ & - & - \\
\hline \multicolumn{5}{|c|}{ 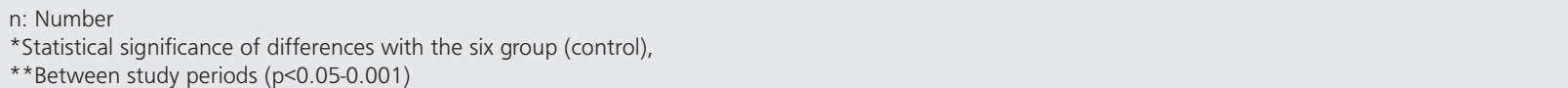 } \\
\hline
\end{tabular}


$14^{\text {th }}$ days by $16.2 \%$ and $35.5 \%$, respectively $(p<0.05)$. In the $4^{\text {th }}$ group, EGF level increased both in blood (by $61.2 \%, p<0.01$ ) and in urine (by $28.7 \%$ ). In the $5^{\text {th }}$ group, the dynamics of EGF values showed a decrease in blood (by $60.0 \%, p<0.01$ ) and in urine (by $11.0 \%$ ).

Multidirectional relationships were revealed when determining the correlation coefficient between the NGF values in blood and urine (Table 3). A statistically significant positive correlation was observed between blood and urine NGF values in the $2^{\text {nd }}$ group on the $14^{\text {th }}$ day of the study. In the control group, there was a weak positive correlation between the values of NGF in the blood and urine.

When determining the correlation coefficient in experimental animal models between the values of EGF in blood and urine, multidirectional relationships were revealed (Figure 1). The study showed that a high direct correlation, which was detected in group 1 a day after modeling, to average after 14 days; in the $2^{\text {nd }}$ group was reduced to very weak, in the $3^{\text {rd }}$ and $4^{\text {th }}$ groups the

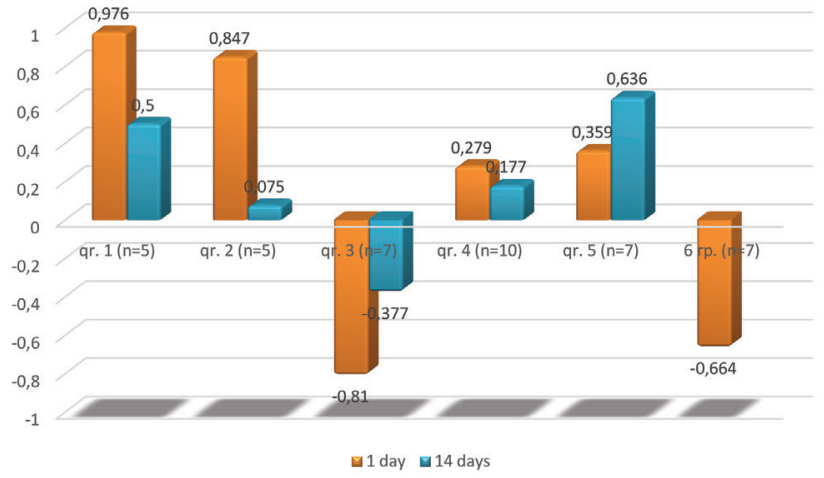

Figure 1. Correlation coefficient ( $r$ ) between indicators of epithelial factor in blood and urine of study groups relationship was also weakened while the correlation in the $5^{\text {th }}$ group decreased from moderate to noticeable. In animals of control group, EGF in the blood and urine were moderately correlated.

Determination of the correlation between the NGF and EGF during the study revealed a tendency to increased correlation between these markers on the $14^{\text {th }}$ day (Figure 2). In the control group, the average indirect correlation was determined between NGF and EGF in blood and urine. Among the $1^{\text {st }}, 4^{\text {th }}$ and $5^{\text {th }}$ groups the correlation between NGF and EGF in the blood and urine was increased. One day after modeling, a strong indirect correlation was noted in the $2^{\text {nd }}$ group between the blood indices, but on $14^{\text {th }}$ day the correlation decreased to moderate and became direct. On the contrary, in the urine, the correlation increased and also became direct on day 14 .

\section{Discussion}

It is known that the etiology of IC/BPS includes inflammatory, autoimmune processes, neurotoxicity

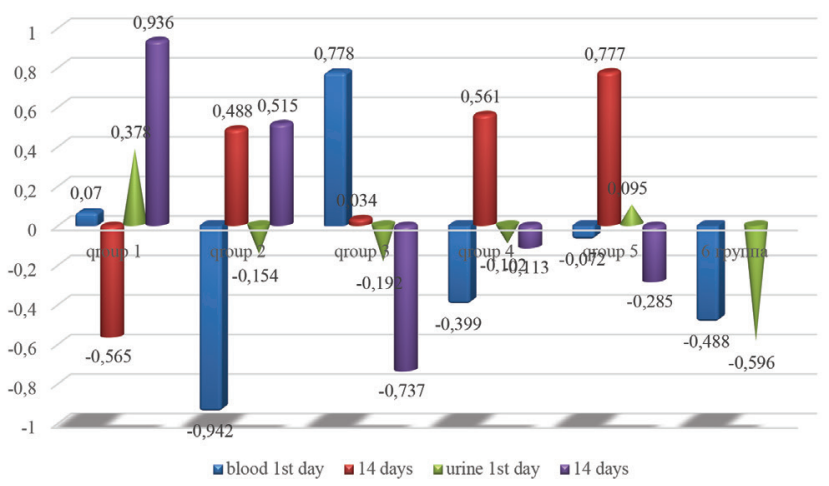

Figure 2. The correlation between nerve growth factor and epidermal factor in the blood and urine

\begin{tabular}{|c|c|c|c|c|}
\hline \multirow{2}{*}{ Groups } & \multicolumn{2}{|l|}{1 day } & \multicolumn{2}{|l|}{14 days } \\
\hline & Blood, pg/mL & Urine, $\mathrm{pg} / \mathrm{mL}$ & Blood, pg/mL & Urine, $\mathrm{pg} / \mathrm{mL}$ \\
\hline $1(n=5)$ & $\begin{array}{l}23.78 \pm 11.86 \\
(7.9,36.6)\end{array}$ & $\begin{array}{l}15.92 \pm 1.58 \\
(13.7,18.0)\end{array}$ & $\begin{array}{l}34.64 \pm 1.98 \\
(29.7,37.0)\end{array}$ & $\begin{array}{l}15.80 \pm 0.75 \\
(15.0,17.0)\end{array}$ \\
\hline $2(n=5)$ & $\begin{array}{l}29.1 \pm 8.0 \\
(15.4,43.2) \\
\end{array}$ & $\begin{array}{l}19.96 \pm 3.61 \\
(13.8,23.4) \\
\end{array}$ & $\begin{array}{l}24.38 \pm 4.46 \\
(17.2,35.0) \\
\end{array}$ & $\begin{array}{l}12.88 \pm 0.78^{* *} \\
(11.6,14.1)\end{array}$ \\
\hline $3(n=7)$ & $\begin{array}{l}33.93 \pm 9.79 \\
(12.4,56.0)\end{array}$ & $\begin{array}{l}25.68 \pm 3.19^{*} \\
(17.7,29.1)\end{array}$ & $\begin{array}{l}35.03 \pm 5.99 \\
(25.9,56.0) \\
\end{array}$ & $\begin{array}{l}16.06 \pm 2.23 \\
(13.7,19.4) \\
\end{array}$ \\
\hline $4(n=10)$ & $\begin{array}{l}30.08 \pm 11.56 \\
(8.7,56.2)\end{array}$ & $\begin{array}{l}20.35 \pm 4.47^{*} \\
(11.6,33.0)\end{array}$ & $\begin{array}{l}77.48 \pm 62.26^{*},{ }^{* *} \\
(37.9,388.8)\end{array}$ & $\begin{array}{l}26.2 \pm 2.78^{*} \\
(20.8,33.0)\end{array}$ \\
\hline $5(n=7)$ & $\begin{array}{l}27.67 \pm 12.06 \\
(9.2,44.2)\end{array}$ & $\begin{array}{l}12.76 \pm 2.42 \\
(6.7,16.5)\end{array}$ & $\begin{array}{l}11.06 \pm 1.62^{*}, \text {,* } \\
(8.7,15.4)\end{array}$ & $\begin{array}{l}11.36 \pm 2.47 \\
(6.7,14.7)\end{array}$ \\
\hline $6(n=7)$ & $\begin{array}{l}28.63 \pm 13.24 \\
(4.6,41.5)\end{array}$ & $\begin{array}{l}13.31 \pm 5.59 \\
(5.6,24.5)\end{array}$ & - & - \\
\hline
\end{tabular}




\begin{tabular}{|c|c|c|}
\hline \multirow[t]{2}{*}{ Experimental groups } & \multicolumn{2}{|c|}{ Study period } \\
\hline & after 1 day & 14 days \\
\hline $1(n=8)$ & +0.163 & -0.088 \\
\hline $2(n=7)$ & -0.219 & $\begin{array}{l}+0.715 \\
p=0.05\end{array}$ \\
\hline $3(n=8)$ & $+0,294$ & +0.415 \\
\hline $4(n=15)$ & +0.215 & +0.216 \\
\hline $5(n=7)$ & +0.691 & -0.330 \\
\hline $6(n=8)$ & -0.059 & $\begin{array}{l}+0.880 \\
p=0.01\end{array}$ \\
\hline
\end{tabular}

and vascular components. Besides, urinary toxicity and disappearance of the glycosaminoglycan layer from the superficial urothelium have been proposed to be pathophysiological mechanisms (14). In our study, there was a statistically significant increase in blood concentration of NGF in all experimental groups, but a particularly a high level of NGF concentration both in blood and urine was determined in the $4^{\text {th }}$ group. Due to the penetration of urine through the affected areas, interstitial tissues were irritated resulting in a decrease in the protective properties of the mucous membrane. Chronic inflammation leads to fibrosis of the bladder wall and decrease in the bladder capacity-as a result, wrinkled tissues do not function at full strength, their accumulative and excretory functions are impaired eventually $(3,16)$. Our results are comparable with data from the study by Steers and Tuttle (14).

Our data regarding elevated NGF are consistent with the results of other studies (17-19). NGF was discovered as a secreted protein necessary for the development of sympathetic and peripheral sensory neurons $(20,21)$. A direct relationship has been shown between painful inflammatory conditions in the lower urinary tract and elevated levels of urine NGF level (21). It is believed that urinary NGF plays a key role in the correlation between inflammation and pain stimulation since it is produced by urothelial cells, smooth and fat cells while activating their degranulation and proliferation $(17,22)$.

Many researchers consider NGF as a potential IC/BPS biomarker. It has been established that the level of NGF in the urine can be used as a biomarker for the diagnosis of IC/BPS, for the differential diagnosis of this disease and hyperactive bladder and also may serve as a prognostic factor $(18,23)$. Reports showing that inflammation increased the expression of NGF arouse interest in NGF as an important indicator of IC/BPS inflammation. It has been shown that inflammation caused neuroplasticity leading to increased urinary NGF level and thus IC/ BPS (18). Some authors supposed that NGF played an important role in the pathogenesis of IC/BPS $(18,22)$. The results obtained in this study also indicated an increase in the concentration of another marker-EGF. At the same time, the most marked changes in the level of EGF in blood and urine were identified in the group of the toxic model of IC/BPS that was created by injecting urine into the bladder wall. It should be noted that EGF that belongs to the group of growth factors (cytokines) and is a polypeptide with a molecular weight of 6000 , was first isolated in 1975 (24). It has been established that EGF stimulates cell growth, proliferation and differentiation by binding to its receptor; it is a powerful mitogen and stimulates the synthesis of mRNA, DNA and proteins of epithelial cells (25). We suggest that elevated EGF level is a response to bladder damage caused by chemicals and toxic substances. Taking into consideration that EGF is urothelial and smooth muscle cell mitogen and increases proliferation and also product of many epithelial cells (26-28), it can be assumed that damage to the glucosaminoglycan layer of the bladder by introducing urine into the bladder wall will increase the level of EGF leading to stimulation of cell proliferation. The duration of this condition of the bladder, further enhances the correlation between the level of EGF in the blood and urine, as evidenced by the correlation coefficient in the second experimental group after 14 days of the study. The duration of this condition of the bladder further intensify the correlation between the levels of EGF in the blood and urine as evidenced by the correlation coefficient after 14 days of research in the $2^{\text {nd }}$ group of the experimental model.

\section{Study Limitations}

The results allow us to expand modern ideas about the role of NGF and EGF in IC/BPS and confirm that damage to urothelium can be of a neurogenic nature. Our studies are necessary to study the course of the pathological process, with the goal of subsequent extrapolation of the data for use in human medicine.

\section{Conclusion}

Studies of the level of NGF and EGF in animal models of IC/PBS in dynamics showed their increase. The presence of elevated levels of NGF in the blood and urine of animals with IC/BPS is apparently caused by inflammatory components and a significant increase in NGF levels in animals with a model created by the introduction of urine into the bladder wall with chronic inflammation and toxicity of the components of the urine. Changes in EGF levels may be associated with IC/BPS. The revealed correlation indicates the cause-and-effect relationship. 
The presence of a correlation between NGF and EGF and its strengthening as IC/BPS progresses indicates an increase in proliferation process in the bladder wall. The determination of proliferation markers can be used in the diagnosis and monitoring of IC/BPS. In further studies, along with the study of the level of NGF and EGF, it is advisable to study the level of mast cells in patients with IC/BPS.

\section{Acknowledgments}

The author would like to thank all staff of the Department of Kidney Diseases and Transplantology of The Republican Centre of Diagnosis and Treatment.

Financial Disclosure: No financial support was received for this study.

\section{References}

1. Fang Z, Xu K. Interstitial Cystitis/Bladder Pain Syndrome: a Review and an Update. Curr Bladder Dysfunct Rep 2016;11:391.

2. Patnaik SS, Laganà AS, Vitale SG. et al. Etiology, pathophysiology and biomarkers of interstitial cystitis/painful bladder syndrome. Arch Gynecol Obstet 2017;295:1341-59.

3. Vivas O, Kruse M, Hille B. Nerve Growth Factor Sensitizes Adult Sympathetic Neurons to the Proinflammatory Peptide Bradykinin. Journal of Neuroscience 2014;34:11959-71.

4. Hanno PM, Erickson D, Moldwin R, Faraday MM; American Urological Association. Diagnosis and treatment of interstitial cystitis/bladder pain syndrome: AUA guideline amendment. J Urol 2015;193:1545-53.

5. Gupta P, Gaines N, Sirls LT, Peters KM. A multidisciplinary approach to the evaluation and management of interstitial cystitis/bladder pain syndrome: an ideal model of care. Transl Androl Urol 2015;4: 611-9.

6. Mullins C, Bavendam T, Kirkali Z, Kusek JW. Novel research approaches for interstitial cystitis/bladder pain syndrome: thinking beyond the bladder. Transl Androl Urol 2015;4: 52433.

7. Lamb LE, Janicki JJ, Bartolone SN, Peters KM, Chancellor MB. Development of an interstitial cystitis risk score for bladder permeability. PLoS ONE 2017;12:e0185686.

8. Birder LA. Pathophysiology of interstitial cystitis. International Journal of Urology 2019; 26:12-5.

9. Jhang J-F, Kuo H-Ch. Pathomechanism of Interstitial Cystitis/ Bladder Pain Syndrome and Mapping the Heterogeneity of Disease. Int Neurourol J 2016; 20(Suppl 2): S95-104.

10. National Research Council (US) Committee for the Update of the Guide for the Care and Use of Laboratory Animals. Guide for the Care and Use of Laboratory Animals. 8th edition. Washington (DC): National Academies Press (US); 2011. The National Academies Collection: Reports funded by National Institutes of Health. 246 p.
11. Sand PK. Proposed pathogenesis of painful bladder syndrome/ interstitial cystitis. J Reprod Med 2006;51(3 Suppl):234-40.

12. Bayrak O, Seckiner I, Solakhan M, Karakok M, Erturhan SM, Yagci F. Effects of intravesical dexpanthenol use on lipid peroxidation and bladder histology in a chemical cystitis animal model. Urology 2012;79:1023-6.

13. Schrepf A, O'Donnell M, Luo Y, Bradley CS, Kreder K, Lutgendorf S. Inflammation and inflammatory control ininterstitial cystitis/bladder pain syndrome: Associations with painful symptoms. PAIN 2014;155:1755-61.

14. Steers WD, Tuttle JB. Mechanisms of disease: the role of nerve growth factor in the pathophysiology of bladder disorders. Nat Clin Pract.Urol. 2006;3:101-10.

15. Qu H-C, Zhang W, Yan S, Liu Y-L, Wang P. Urinary Nerve Growth Factor Could Be a Biomarker for Interstitial Cystitis/ Painful Bladder Syndrome: A Meta-Analysis. PLoS One 2014;9: e106321.

16. Liu H-T, Kuo H-C. Biomarkers for patients with interstitial cystitis/bladder pain syndrome. Urological Science 2015;26:225-9.

17. Kim SR, Moon YJ, Kim SK, Bai SW. NGF and HB-EGF: Potential Biomarkers that Reflect the Effects of Fesoterodine in Patients with Overactive Bladder Syndrome. Yonsei Med J 2015;56: 204-11.

18. Tonyali S, Ates D, Akbiyik F, Kankaya D, Baydar D, Ergen A. Urine nerve growth factor (NGF) level, bladder nerve staining and symptom/problem scores in patients with interstitial cystitis. Advances in Clinical and Experimental Medicine 2018;27:159-63.

19. Chang D, Hsu E, Hottinger D, Cohen SP Anti-nerve growth factor in pain management: current evidence. J Pain Res 2016;9:373-83.

20. Kwon W-A. Animal Model of Interstitial Cystitis/Bladder Pain Syndrome. Int Neurourol J 2018;22(Suppl 1):S1-2.

21. Cohen S, Carpenter G. Human epidermal growth factor: isolation and chemical and biological properties. Proc Natl Acad Sci USA 1975;72:1317-21.

22. Meybosch S, De Monie A, Anné C. et al. Epidermal growth factor and its influencing variables in healthy children and adults. PLOS ONE 2019;14:e0211212.

23. Keay SK, Zhang CO, Shoenfelt J. et al. Sensitivity and specificity of antiproliferative factor, heparin-binding epidermal growth factor-like growth factor, and epidermal growth factor as urine markers for interstitial cystitis. Urology 2001;57(6 Suppl 1):9-14.

24. Kuo H-C, Liu H-T, Shie J-H. Potential urine and serum biomarkers for patients with overactive bladder and interstitial cystitis/ bladder pain syndrome. Tzu Chi Medical Journal 2013; 25:13-18.

25. Chen W, Ye DY, Han DJ, Fu GQ, Zeng X, Lin W, Liang Y. Elevated level of nerve growth factor in the bladder pain syndrome/interstitial cystitis: a meta-analysis. Springer plus 2016;5:1072. 
26. Song PH, Chun SY, Chung JW. et al. Comparison of 5 different rat models to establish a standard animal model for research into interstitial cystitis. Int Neurourol J 2017;21:163-70.

27. Birder L, Andersson K-E. Animal Modelling of Interstitial Cystitis/Bladder Pain Syndrome. Int Neurourol J 2018;22(Suppl 1):S3-9.
28. Buffington T, Ruggieri MR, Klumpp D. Interstitial cystitis: Animal models. In Bladder Pain Syndrome - An Evolution. Springer International Publishing 2017:33-6. 